\title{
Aikuisen opiskeluprosessi ja etäopetus
}

\section{Kokemuksia ammatillisesta aikuiskoulutuksesta}

\begin{abstract}
Rajala, Raimo 1989. Aikuisen opiskeluprosessi ja etäopetus. Kokemuksia ammatillisesta aikuiskoulutuksesta. Aikuiskasvatus 9, 1.24-27.

- Artikkelissa tarkastellaan ammatillisessa aikuiskoulutuksessa olevien opiskelijoiden opiskeluprosessia. Osa opiskelijoista opiskelee lähiopetuksena ja osa etäopiskelua soveltaen ammattioppilaitoksen iltalinjoilla. Lähi- ja etämuotoisesti opiskelevien opiskeluprosessi näyttää eroavan tietyissä suhteissa. Etäopiskelusta näyttää olevan hyötyä opiskelussa. Opintojen esteiden ja opintoihin liittyvien huolten rooli on vähäisempi opiskeluun sopeutumisessa etämuotoisesti opiskelevilla.
\end{abstract}

Lapin läänissä on vuodesta 1986 toteutettu Lapin aikuiskoulutusprojektia. Projektin tavoitteena on aikuiskoulutuksen osalta alentaa aikuisten opiskeluun osallistumisen kynnystä. Eräänä keinona opintososiaalisen tuen ohella kokeilussa käytetään perinteistä lähiopetusmallia muuntavaa etäopetusta. Etäopetusta on sovellettu mm. Tornion Liiketalouden ja Tietotekniikan Instituutin atk-vastuuhenkilökoulutuksessa ja Rovaniemen ammattioppilaitoksen viidellä iltalinjalla. Etäopetuksen käsite ja muodot eivät ole vielä vakiintuneita. Tässä yhteydessä etäopetuksella tarkoitetaan sellaisia opetuksen järjestelyjä, joissa aikuisopiskelija voi suorittaa ainakin osan opinnoissaan normaalin lähiopetuksen ulkopuolella. Hän opiskelee kotona tai paikassa voidaan toimittaa postitse. Opiskelija opiskelee kotona opettajan toimittaman materiaalin ja ohjeiden mukaisesti. Halutessaan jompi kumpi osapuoli yleensä opettaja - voi ottaa yhteyttä toisiinsa.

Rovaniemen ammattioppilaitoksen viidellä iltalinjalla (dieettikeittäjä, suurtalouskokki, kiinteistönhoitaja, parturi-kampaaja ja sähköasentaja) on sovellettu etäopetusta. Jatkossa esiteltävä aineisto on kerätty aikuisopiskelijoilta $(\mathrm{N}=59$; palautusprosentti 91$)$, jotka ovat aloittaneet lukuvuonna 1987-88. Heidän vertailuaineistonaan on käytetty Tampereen ammattioppilaitoksen kolmea linjaa $(\mathrm{N}=40$; palautusprosentti 84), joilla opetus tapahtuu normaalina lähiopetuksena (suurtalouskokki, parturi-kampaaja ja sähköasentaja).
Tässä artikkelissa keskitytään kahteen ongelmaan:

1. millainen on ammatillisten aikuisopiskelijoiden opiskeluprosessi ja

2) mikä on etäopetuksen merkitys opiskeluprosessin kannalta. Vastaus näihin kysymyksiin saatiin analysoimalla kerätty aineisto tilastollisesti.

\section{Aikuisen opiskeluprosessi}

Aikuisten opiskeluun osallistumista on yleisimmin tutkittu osallistumismotiivien ja -esteiden näkökulmasta (esim. Mäki 1977; Haven \& Syvänperä 1983; Alanen 1985; Piekka 1983). Lehtonen ja Tuomisto (1976) ovat lähestyneet aikuisopiskelua monivaiheisena aktivoitumisprosessina. Koulutuspalveluiden käyttöön vaikuttavat yhteiskunnan rakennetekijöiden säätelemä osallistumishalukkuus, tieto koulutuspalveluista ja arviointi palveluiden vastaavuudesta suhteessa omiin tarpeisiin. Koulutuspäätöksen jälkeen palveluita arvioidaan ja kielteisessä tapauksessa opinnot keskeytetään. Aaltonen ja Manninen (1979) ovat täydentäneet perusmallia lisäämällä palvelusten hyväksikäyttöön vaikuttavaksi tekijäksi itse koetut osallistumisesteet. Aho (1983) on laajentanut aikuisen opiskelumallia reaalisen opiskeluprosessin ja opettajan ja opiskelijan välisen vuorovaikutuksen kuvauksella. Hänen mallinsa perustuu Tinton (1975) korkeakouluopiskelijoiden keskeyttämismalliin. Sen mukaan keskeyttäminen on 
seurausta yhtäältä yksilön ja sosiaalisen järjestelmän vuorovaikutuksen riittämättömyydestä ja toisaalta järjestelmän ja yksilön arvojen ristiriidoista. Jaakkola (1987) analysoi aikuisopiskelijoiden reaalisia opiskelutyylejä ja etsii persoonallistekijöistä ja opintojen esteistä tyylien ennustemuuttujia. Hän ei kiinnittänyt huomiota siihen, miten opiskelutyylit ovat yhteydessä opinnoissa menestymiseen tai opiskelutyytyväisyyteen.

Rajalan ja Saarisen (1988) tutkimuksessa ammatillisten aikuisopiskelijoiden opiskeluprosessia tarkasteltiin muuttuneeseen elämäntilanteeseen sopeutumisen näkökulmasta. Aikuisena opiskelun aloittaminen nähtiin erityistä sopeutumista vaativaksi elämänmuutokseksi, joka saattaa muodostua yksilöstä toiseen vaihdellen hyvinkin kuormittavaksi tilanteeksi. Kognitiivisesti suuntautunut stressi- ja hallintateoria (Lazarus \& Folkman 1984; Rajala 1988) on käsitteellistänyt luonteeltaan stressaavan yksilö-ympäristösuhteen seuraaviksi keskeisiksi muuttujiksi: ympäristön asettamat vaatimukset tai ympäristössä esiintyvät esteet, ympäristön vaatimusten kognitiivinen arviointi, yksilön keinot käsitellä luonteeltaan stressaavaa tilannetta ja yksilön sopeutumista kuvaavat lopputulokset emootioiden ja psykosomaattisen terveydentilan muodossa.
Opiskeluprosessia voidaan lähestyä yksilön ja opintoympäristön vuorovaikutuksena. Opiskelijan opiskelutyylit edustavat tämän vuorovaikutuksen kannalta tarkoituksenmukaisia tapoja tulla toimeen opiskelutehtävien asettamien vaatimusten kanssa (ks. esim. Marton \& al. 1980). Lisäksi opiskelija voi käyttää erilaisia hallintakeinoja selviytyäkseen opiskeluongelmistaan. Se, kuinka hyvin opiskelija sopeutuu opiskelutilanteeseen (alhainen psyykkinen kuormittuminen ja keskeyttämishalukkuus), toimii osoittimena hänen käyttämiensä opiskelutyylien ja hallintakeinojen tarkoituksenmukaisuudesta.

Tässä yhteydessä opiskeluprosessilla tarkoitetaan muuttujien välisten suhteiden analysoinnin perusteella muodostettua mallia, jossa edeltävien tekijöiden (opintojen esteet) 'vaikutus' kulkee opiskelutilanteeseen sopeutumista osoittaviin indikaattoreihin välittävinä tekijöinä toimivien opiskelutilanteen kognitiivisten arviointien ja opiskelijan toiminta kuvaavien muuttujien kautta. Opiskelemaan hakeutumisen motiiveja ja persoonallisuutta pidetään opiskeluprosessin reunaehtoihin kuuluvina suhteellisen pysyvinä tekijöinä.

Kuvio 1 esittää pelkistetyn opiskeluprosessin mallin, joka on muodostettu Rovaniemen ja Tampereen aineiston pohjalta.

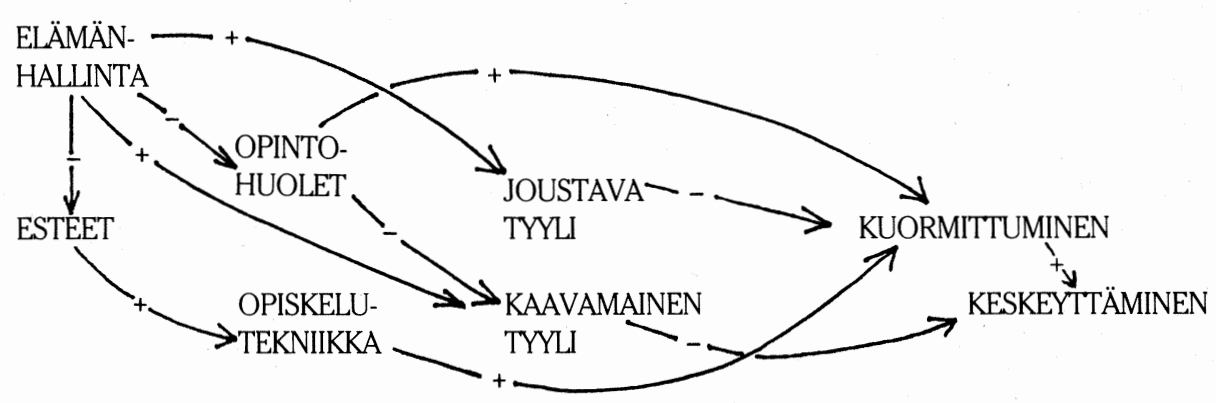

+ ja - = muuttujien välisen yhteyden suunta

Kuvio 1. Aikuisopiskelijan opiskeluprosessin malli

Analyysien perusteella voidaan aikuisopiskelijan opiskeluprosessista muodostaa seuraavanlainen malli. Opiskelun rakenteelliset esteet, joita olivat mm. työ, perhe, työnantajan ja perheen suhtautuminen, vaikuttavat opiskelutekniikkaan liittyvien huolenaiheiden kautta korkeaan opinnoissa kuormittumiseen, mikä on edelleen yhteydessä korkeaan keskeyttämishalukkuuteen. Yleensä opintoihin liittyvän informaation käsittely huolten näkökulmasta en- nustaa korkeaa kuormittumista. Mikään opiskelijoiden käyttämistä opiskeluongelmien hallintakeinoista ei sijoitu malliin. Sen sijaan kaksi opiskelutyyliä tulee mukaan. Joustava opiskelutyyli, jolle on tunnusomaista erittelevyys, harkitsevuus ja opitun käyttö uusissa tilanteissa, ennustaa alhaista kuormittuneisuutta opinnoissa. Kaavamainen tyyli, jolle on leimallista annettujen ohjeiden mukainen työskentely sekä avun ja neuvojen pyytäminen, ennustaa 
myöskin alhaista kuormittumista.

Elämänhallinta, jolla tarkoitetaan opiskelijan uskomusta mahdollisuudesta vaikuttaa omaan elämäänsä, ennusti aikuisopiskelijan opiskelun lähtökohtatilannetta, opintojen esteitä. Hyvän elämänhallinnan omaavilla opiskelijoilla esiintyi vähän esteitä. Se ennusti myös tapaa käsitellä opiskelutilanteesta saatavaa informaatiota. Hyvän elämänhallinnan omaavat opiskelijat käsittelivät opiskelutilannettaan vähemmän huolikeskeisesti. Elämänhallinta oli myös yhteydessä opiskelijoiden tapaan lähestyä opiskelutehtäviä. Opiskelijat, jotka luottivat omiin voimiinsa, edustivat joustavaa ja kaavamaista opiskelutyyliä. Molemmat tyylit olivat opiskeluun sopeutumisen kannalta tarkoituksenmukaisia.

\section{Etäopetuksen merkitys aikuisopiskelussa}

Mallin rakentelussa käytettiin eräänä muuttujana myös 2-luokkaista muuttujaa etäopiskeluun osallistumisesta ( $0,1=$ osallistunut $)$. Ne aikuisopiskelijat, jotka suorittivat opintojaan etäopiskeluna, erosivat ryhmänä lähiopiskelijoista kahdessa suhteessa: he olivat taipuvaisia käsittelemään opiskelutilannetta huolten näkökulmasta ja heillä oli useimmiten epätarkoituksenmukainen opiskelutyyli (ei-joustava ja eikaavamainen).

Määrällisesti etäodetus vaihteli $1 \ldots 11 \mathrm{~h} /$ viikko. Eri linjojen välillä oli myöskin määrissä eroja. Tyypillinen paljon etämuotoisesti opiskeleva oli keski-ikäinen mies, jolla on alhainen pohjakoulutus ja runsaasti työkokemusta. Koulutukseen hakeutumisen motiivit ovat pikemminkin sattumanvaraisia kuin itse tiedostettuja ja tahdottuja. Lisäksi hän kokee opinnot kuormittaviksi, ja keskeyttämishalukkuus on korkeahko.

Etäopetuksen mahdollisia suotuisia vaikutuksia analysoitiin seuraavasti. Edellä esitetyn opiskeluprosessin mallin kannalta kriittisiä kohtia opiskelussa näyttivät olevan esteiden ja opiskeluun sopeutumisen (kuormittuminen ja keskeyttäminen) suhde, huolten yhteys sopeutumiseen sekä opiskeluongelmien hallintakeinojen ja opiskelutyylien yhteys sopeutumiseen.

Jos etäopetuksesta on menetelmänä hyötyä, niin voimme odottaa kahden ensimmäisen kohdan osalta etäryhmässä heikompaa yhteyttä kuin lähiryhmässä. Kolmannen kohdan osalta adaptiivisten hallintakeinojen ja opiskelutyylien yhteydet ovat etäryhmässä voimakkaampia.

Aineisto analysoitiin jakamalla etäryhmä kolmeen suurin piirtein yhtäsuureen osaryhmään opetuksen määrän mukaan: vähän (1$2 \mathrm{~h} / \mathrm{vk})$, keskinkertaisesti ( $3-5 \mathrm{~h} / \mathrm{vk})$ ja paljon $(6+\mathrm{h} / \mathrm{vk})$. Osaryhmien ja lähiopetusryh- män välisten korrelaatiokerrointen suuruuden perusteella tarkasteltiin olettamusten paikkansa pitävyyttä.

Tulokset osoittivat, että keskimääräisesti etäopiskelevilla ( $3 \ldots 5$ h/viikko) opintojen esteiden ja opintohuolien vaikutus sopeutumiseen oli vähäisempi kuin lähiryhmässä. Hallintakeinojen ja opiskelutyylien osalta suotuisat vaikutukset olivat vähäisiä. Ongelmanratkaisusta ja merkityksen etsimisestä pulmatilanteessa oli hyötyä sopeutumiselle, jos etäopetusta oli alle $3 \mathrm{~h} /$ viikko. Sen sijaan etäopiskelijat, joilla oli analyyttinen, joustava ja kaavamainen opiskelutyyli, sopeutuivat paremmin opiskeluun, jos etäopetusta oli alle $3 \mathrm{~h} /$ viikko tai $3 \ldots 5 \mathrm{~h} /$ viikko. Jos etäopetusta oli yli 6 h/viikko, niin suotuisa vaikutus hävisi.

\section{Johtopäätöksiä}

Tämän tutkimuksen perusteella ammatillisten aikuisopiskelijoiden opiskeluprosessi on ongelmallinen. Alhainen pohjakoulutustaso ja alhainen elämänhallinta ennustavat opiskelun lähtökohtatilannetta, jolle on tunnusomaista monien opiskelutilanne huoliväritteisenä. Nämä tulokset ovat yhdenmukaisia muissa kuin oppimistilanteissa tapahtuvaa sopeutumista analysoiviin tutkimuksiin. Elämänhallinnan ja muiden persoonallisuuden ominaisuuksien on havaittu olevan tekijä, joka tekee haavoittuvaiseksi stressille ja johtaa huonoon sopeutumiseen (ks. esim. Pearlin \& Schooler 1978: työn ongelmat; Menaghan 1983: vanhemmuus, avioliitto, työ; Rajala 1988: opettajien työ).

Tutkimuksen tulokset antavat aihetta sen pohtimiseen, kuinka ongelmallista koulutusyhteiskunnassa siirtymä työelämästä eri muotoiseen koulutukseen ja takaisin työelämään itse asiassa on. Tutkimuksen tulosten mukaan elämänhallinta näyttelee keskeistä osaa opiskeluprosessissa. Se on yhteydessä hakeutumismotiiveihin ja koko opiskeluprosessin kulkuun. Koulutusyhteiskunta painottaa määrätietoista elämänsuunnitelmien täsmentämistä ja jatkokoulutuksen suunnittelua myös koulutettavien itsensä taholta.

Koulutukseen hakeutumisen motiivien keskeisyyttä painottaa myös tulos, jonka mukaan erityisesti joustavaa ja monipuolista opiskelutyyliä ennustivat ammattiin sisäisesti kohdistuvat kiinnostukset. Ammattiin kohdistuva kiinnostus näyttää virittävän tarkoituksenmukaisempia opiskelutyylejä, jotka ennustavat parempaa opiskeluun sopeutumista.

Etäopiskelua koskevat tulokset viittaavat etämuotoisen opiskelun suotuisiin vaikutuksiin. Opintojen esteillä ja opintoihin liittyvillä huolilla on etämuotoisessa opiskelussa vähäisempi merkitys opiskelutilanteeseen sopeutumisen kannalta. Opiskelutyylejä koskeva tulos 
viittaa siihen, että etämuotoisessa opiskelussa selviytyminen (so. vähäinen kuormittuminen ja alhainen keskeyttämishalukkuus) saattaa ainakin tässä aineistossa vaatia opiskelijoilta joko hyvin kehittynyttä opiskelutyyliä (analyyttinen ja joustava) tai opettajan ohjeiden mukaan työskentelevää opiskelijaa (riippuvaisen ja 'kiltin oppilaan' malli).

Tutkimuksen tulokset antavat aihetta moniin ammatillisen aikuisopintojärjestelmän toimintaa koskeviin huomioihin. Ensinnäkin aikuisopintojärjestelmän tulee toiminnassaan ottaa huomioon erilaiset lähtökohdat. Alhaisen elämänhallinnan ja pohjakoulutustason epäsuotuisien vaikutusten kompensoimiseksi on paikallaan lisätä opinto-ohjausta ja opiskelutekniikan opettamista. Toisaalta opintojärjestelmää voidaan varmasti kehittää siten, että se ottaisi huomioon opiskelijan aikaisemman tietopohjan ja työkokemuksen. Toiseksi etämuotoinen opiskelu ei välttämättä sovi kaikille. Etäopiskelun pedagogisella kehittämisellä voitaneen lisätä sen mahdollisuuksia soveltua moniaineksisemmalle opiskelijajoukolle. Nykyisellään etämuotoisesta opiskelusta on selvää hyötyä: se vähentää opintojen esteiden ja alhaisesta pohjakoulutustasosta juontuvien opintohuolten haitallista vaikutusta opiskelussa. Opiskelutilanteeseen sopeutumisen kannalta etäopiskelusta hyötyvät erityisesti kehittyneen opiskelutyylin omaavat aikuisopiskelijat, mikä ei välttämättä ole sopusoinnussa tyypillisten etäopiskelijoiden ominaisuuksien kanssa.

\section{Lähteet}

Aaltonen, R. \& Manninen, H. 1979. Aikuisopiskelu ja kulttuuripalvelusten käyttö sosiaalisen osallistumisen muotona. Tampereen yliopisto. Aikuis- ja nuortenkasvatuksen laitoksen julkaisuja 13.

Aho, S. 1983. Opiskeluvaikeudet ja opintojen keskeyttäminen kansalais- ja työväenopistoissa. Opintonsa keskeyttäneiden ja loppuunsuorittaneiden opiskelijoiden käsitykset opiskelutavoitteistaan ja -vaikeuksistaan sekä opettajien opetustaidosta. Turun yliopisto. Kasvatustieteiden tiedekunta. Julkaisusarja A:94.

Alanen, A. 1985. Johdatus aikuiskasvatukseen. Helsinki: Yleisradion opetusohjelmat.

Haven, H. \& Syvänperä, R. 1983. Aikuiskoulutukseen osallistuminen. Tilastokeskuksen tutkimuksia 92.

Jaakkola, R. 1987. Aikuisopiskelijoiden itsearvioimat oppimistyylit. Avoimen korkeakoulun ja kansalaisopistojen kielten opiskelijoiden itsearvioitujen oppimistyylien tarkastelua. Lisensiaattitutkimus. Tampereen yliopisto. Aikuis- ja nuorisokasvatuksen laitos.

Lazarus, R. \& Folkan, S. 1984. Stress, appraisal and coping. New York: Springer.

Lehtonen, H. \& Tuomisto, J. 1976. Aikuisväestön opinnollisen aktivoitumismuuttujan konstruoinnista ja käyttökelpoisuudesta. Tampereen yliopisto. Aikuis- ja nuorisokasvatuksen laitoksen julkaisuja 9 .

Marton, F., Dahlgren, L., Svensson, L. \& Säljö, R. 1980. Oppimisen ohjaaminen. Espoo: Weilin + Göös.

Menaghan, E. 1983. Individual coping efforts: Moderators of the relationship between life stress and mental health outcopmes. In H. Kaplan (Ed.) Psychosocial stress: Trends in theory and research. New York: Academic Press (157191).

Mäki, T. 1977. Opiskelun tavoitteet ja jatkuvuus sekä opetuksen yleissuunnittelu kansalaisopistoissa. Tutkimuksia eräistä kansalais- ja työväenopistojen aineryhmistä. Tampereen yliopisto. Psykologian laitoksen tutkimuksia 106.

Pearlin, L. \& Schooler, C. 1978. The structure of coping. Journal of Health and Social Behavior, 19, 2-21.

Piekka, P. 1983. Tietoja ammatilliseen aikuiskoulutukseen osallistumisesta ja ammatillisen aikuiskoulutuksen tarpeesta. Ammattikasvatushallitus. Suunnittelu- ja kehittämisosasto. Selosteita ja tiedotteita.

Rajala, R. 1988. Teachers stress and coping: The effectiveness of coping efforts from prospective perspective. University of Lapland Publications in Education A:3.

Rajala, R. \& Saarinen, J. 1988. Ammatillisen aikuisopiskelijan opiskeluprosessi opiskelutilanteeseen sopeutumisen näkökulmasta (käsikirjoitus).

Tinto, V. 1975. Dropout from higher education: A theoretical synthesis of recent research. Review of Educational Research, 45, 89-125. 


\section{AIKUISKASVATUS \\ The Finnish Journal of Adult Education \\ Vol. 9,1/89 \\ ISSN 0358-6197 \\ Summary}

Rajala, Raimo 1989. The study process of adults and distance education. Vocational adult education experiences.

- The article deals with the study process of students participating in vocational adult education. Students enrolled in evening vocational lines may either attend classes of study some parts of their courses at home applying distance education. The study process of the two groups seemed to differ in some regards. Students seemed to benefit from distance education; the effects of study obstacles and worries concerning one's abilities as student were less important to adaptation to study. 